\title{
Effect of Processing on Selected Nutrient Profile of Seeds used for Inclusion in Energy Bars of Sports Person
}

\author{
Diksha Sharma* and Sangita Sood \\ Department of Food Science, Nutrition and Technology, College of Community Science, \\ CSKHPKV, Palampur, India \\ *Corresponding author
}

\begin{abstract}
A B S T R A C T
\section{Keywords}

Nutritional profile, Oilseeds, Energy bar, Sports person and Sports nutrition

Article Info

Accepted:

20 August 2020

Available Online:

10 September 2020

The present investigation was carried out to study effect of processing on the seeds which were used for inclusion in the energy bars of sports person. The seeds selected for the study were Flax, Chia, Pumpkin and Finger millet seeds. Proximate parameters and mineral estimation were done to assess the nutritional profile of all the seeds. The result shows that protein content of the seeds were increased significantly during germination while it was decreased significantly during roasting and popping. Pumpkin seeds and Chia seeds showed $26.43 \%$ and $8.24 \%$ increase in crude protein during germination as compared to raw seeds. Finger Millet showed non-significant difference in crude protein content, crude fiber, crude fat and carbohydrate content during processing. Roasted and popped Chia seeds had significant increase of $2.94 \%$ and $0.45 \%$ in energy. Roasting and popping significantly decreased calcium, phosphorus and iron content of Finger millet and pumpkin seeds. Iron was increased in Chia seeds during roasting from $4.36 \mathrm{mg} / 100 \mathrm{~g}$ to $5.71 \mathrm{mg} / 100 \mathrm{~g}$. Processed Finger millet showed non-significant differences in the iron and calcium. It can be concluded that pre-treatment help in enhancing the nutritional profile of all the seeds.
\end{abstract}

\section{Introduction}

Nowadays, sports has become one of the most demanding and competitive profession in the world. Today sports person's demands the best starting from coaching to his food. The role of nutrition in athletic performance has been acknowledged from a very long time. Sports nutrition is fairly a new discipline involving the application of nutritional principles to enhance the athletic performance. In general "Sports nutrition" can be defined as, a special application of nutritional science to enhance performance in sports. Well balanced diet which is derived from all macro and micro nutrients is important to become all rounder whether it is gymnastics, swimming or any other sport.

The demand for healthy and nutritious food is growing worldwide. Intake of balanced diet in correct way helps to prevent or even remedy health problems, such as obesity, diabetes, malnutrition, cardiovascular and others, 
which largely originate from dietary mistakes (Marques et al., 2015). Consumers demand and desire for the health and safe food, which are portable, convenient and proportioned as well. Multigrain bar meet up this trend and is elaborated from the mass of grains of sweet and pleasant taste, and is a source of vitamins, minerals, fiber, protein and complex carbohydrates (Izzo and Niness, 2001). These multigrain bars use a variety of ingredients that scatter to various segments of consumers (Palazzolo, 2003). The bar has gained fame and attractiveness in the global market during recent years and today the market is offering wide range of bars under different names like chewy cereal granola bar, snack bar, organic bar, Chocó bar, muffin bar, fruit filled bar and so on. The utilization of different bars was increased 11 per cent globally in 2007 and it represents a market of about US \$ 4 billon leading to an increase in the variety of bars and different ingrates in order to excite consumers (Sharma et al., 2014). Now indigenously prepared diverse types of bars are becoming popular among Indian consumers (Ananthan, 2012).

The main source of protein in energy bars are oilseeds such as Flax seed, chia seed, pumpkin seed etc. Flaxseed is also known as linseed and these terms are used interchangeably. Flaxseed is often used to describe flax when consumed by humans while linseed denotes when it is used specifically for industrial applications (Morris, 2004). Flaxseed has been recognized as potential functional food source owing to its bioactive components-omega-3 fatty acid, lignans and dietary fiber (Kajla et al., 2015). Traditionally, Chia seeds were used by Aztecs and Mayas people in the preparation of folk medicines, food and canvases. It is oilseed, with a power house of omega-3 fatty acids, superior quality protein, and higher extent of dietary fiber, vitamins, minerals and wide range of polyphenolic antioxidants which act as antioxidant and safeguard the seeds from chemical and microbial breakdown (Cahill, 2002). Pumpkin seeds can be consumed by different age groups as boiled, fried snack or added to stew to eat yam (Agbagwa and Ndukwu, 2004).

They can serve as a good source of lipids, proteins, carbohydrates and other nutrients that are important for maintaining good health (Alfawaz, 2004). Pumpkin seeds have exhibited pharmacological properties such as anti-diabetic (Caili et al., 2006), antifungal, antibacterial, anti-inflammation and antioxidant (Wang and $\mathrm{Ng}, 2003$ ). Finger Millet also known as ragi is a good source of nutrients especially calcium, iron, phosphorus, potassium, other minerals and fiber.

Raw oilseeds cannot be used raw due to misconception among the consumers, as these have antinutritional factors. Anti-nutritional factors such as phytic acid, cyanogenic glycosides may have negative impact on heath and mineral absorption in the body. To overcome these oilseeds need to be processed before its inclusion in the energy bars. Processing methods have been traditionally used in India to enhance the nutritional quality of food stuffs. Different methods can be used for processing of oilseeds viz. roasting, popping and germination. Roasting helps in improving the quality, flavor, texture and acceptability of the oilseeds (Özdemir and Devres, 2000a; Pittia et al., 2001). Germination maximizes the optimum level of absorbable nutrients and improves the nutritive quality of seeds with reduction in the level of anti-nutrients (Inynag and Zakari, 2008). Roasting is also one of the major step in processing of seeds and it enhances flavor, color and texture. Therefore an attempt has been made in the present study to study effect of processing methods (roasting, popping and germination) on the seeds which will be used for making energy bars for the sports person. 


\section{Materials and Methods}

The Flax, Chia, Pumpkin and Finger millet seeds were procured from the local market of Palampur. The other raw materials like Honey (Dabur), Peanut butter (sun drop) and Jaggery were also purchased from the local market for the development of energy bar. Packaging material such as butter paper and Aluminium foil, used for packaging of final product.

\section{Preparation of sample}

The procured seed samples were cleaned manually for removing adhering dirt, dust and foreign particles. The seeds were ground into a fine powder with the help of stainless steel grinder and stored in air tight food grade polyethylene terephthalate containers and finally stored in refrigerator till further analysis. The entire analysis was carried out in triplicate. Three treatment i.e. roasting (T1), popping (T2) and germination (T3) were given to the raw seeds (T0) of Flax, Chia, Pumpkin and Finger millet seeds.

\section{Control (T0)}

The fresh seeds without any treatment dried in a hot air oven $65 \pm 2^{\circ} \mathrm{C}$ for 5-6 hours.

\section{Roasting (T1)}

The Seeds $(250 \mathrm{~g})$ were roasted in preheated iron skillet at $128^{\circ} \mathrm{C}$ for 2.5 minutes till the pleasant aroma developed. Roasted seeds were taken out from the skillet and spread on a tray for rapid cooling

\section{Popping (T2)}

Prior to popping the standardization was done for soaking the seeds in water to gain moisture so as to obtain good popping yield. Initially the seeds were soaked for from $5 \mathrm{~min}$ till 30 minutes. The popping was done after drying the seeds on filter paper at the interval of 5 minutes and the final time for soaking was $10 \mathrm{~min}$ to obtain the good popping yield. Popping was done by dropping the seeds in a preheated cauldron and moving with the help of molded cloth until the seeds were popped.

\section{Germination (T3)}

The seeds were germinated in a home scale sprout box in ambient temperature. The seed were washed with water and placed as single layer in sprout box filled with water. The water in box was changed every day and seeds were checked for germination. The seeds took about 3-4 days to germinate and then the germinated seeds were dried in hot air oven at $65 \pm 2^{\circ} \mathrm{C}$ for 5-6 hours.

\section{Storage of processed seeds}

The seeds were ground into a fine powder with the help of stainless steel mixer grinder and stored in airtight food grade polyethylene terephthalate containers and finally kept in refrigerator for further analysis.

\section{Nutritional evaluation of seeds}

Moisture, ash, crude fat, crude fiber were determined as per standard method as suggested by AOAC (2010). Nitrogen was analyzed by Micro-kjeldhal method as outlined by AOAC (2010) and was multiplied by factor 5.83 for converting it into crude protein.

Carbohydrate was calculated by calculation method. Formula of carbohydrate is given below

Carbohydrate $(\%)=100-($ Moisture + Crude protein + Crude fat + Crude fiber + Total ash) Energy was calculated by factorial method. Formula of energy is given below 
Energy $(\mathrm{Kcal})=4 \mathrm{x}$ Carbohydrate $+4 \mathrm{x}$ Crude protein $+9 \mathrm{x}$ Crude fat

\section{Mineral content of seeds}

All the organic matter in the samples was wet digested with triacid mixture (HNO3:HClO4: $\mathrm{H} 2 \mathrm{SO} 4$; in 9:3:1) and the mineral estimation (Calcium, Phosphorus and Iron) was done by employing Atomic Absorption Spectrophotometer (Model: Perkin-Elmer 3100) available in department of animal nutrition, DGCN COVAS, CSHPKV, Palampur. Phosphorus in the samples was estimated by the method described by Chen $e t$ al., (1956). All the analysis work was carried out in triplicate so as to reduce the experimental error.

\section{Statistical Analysis}

The data obtained for each parameter was statistically analyzed using OP stat statistical package. Data were reported as means \pm standard deviation (SD). The level of significance at $5 \%$ was determined by applying two factorial analysis of variance (ANOVA).

\section{Results and Discussion}

\section{Proximate Composition}

The proximate analysis of the Flaxseed, chia seeds, pumkin seeds and Finger Millet is shown in Table1.

\section{Flaxseed}

Significant differences were observed in crude protein, crude fiber and carbohydrates level of seeds in different processing methods. The raw flaxseed contained 22.18 per cent crude protein which increased to 22.81 per cent during germination whereas decreased to 20.73 per cent and 19.14 per cent during roasting and popping, respectively. A known significant $(p \leq 0.05)$ decreased in protein content was found during popping (19.14 per cent). Germinated flaxseeds showed a significant increase in protein content which might be due to synthesis of hydrolytic enzymes during various events of germination (Bau et al., 1997). The decreased protein content during popping might have been due to denaturation of protein by thermal treatment. Crude fiber content of raw flaxseed was 11.97 per cent which significantly decreased to 8.37 per cent during germination followed by popping 10.11 per cent and roasting 10.61 per cent. A significant decrease in crude fiber content on germination was noticed which might be attributed to the fact that part of the seed fiber may be solubilised enzymatically (El Maki et al., 1999). The highest carbohydrate content was found in popped flaxseed i.e. 24.32 per cent followed by germination 23.91 per cent, roasting 21.35 per cent and raw 17.72 per cent. Singh et al., (2013) and Gopalan et al., (1971) reported $22.9 \%$ to $29.6 \%$ carbohydrates in different flaxseed varieties and concluded that it might be due to the difference in fat and protein in studied flaxseed varieties. Energy was non significantly increased in all the processing treatments. Gopalan et al., (1971) in his study also reported the nutrients per $100 \mathrm{~g}$ of flaxseed as energy content $(530 \mathrm{Kcal})$ which is at par to the present investigation.

\section{Chia seeds}

All the parameters of the proximate analysis showed significant difference among all the treatments. Germinated chia seeds had $8.23 \%$ and $25.19 \%$ increase in crude protein when compared to raw and roasted seeds. The increase in protein content after sprouting (compared to seeds and whole flour) reveals a positive balance between protein degradation and protein biosynthesis during germination. The results of present investigation are in 
accordance with the findings of Benincasa et al., (2019) and Mayer et al., (1982). Crude fat was decreased significantly in all the treatments from $29.54 \%$ to $28.95 \%, 27.90$ and $27.39 \%$ in roasting, popping and germination respectively. A steady decrease in lipid content is a well-defined phenomenon occurring in seed sprouting, promoted by the action of endogenous lipases. The results are in agreement with the findings of Kylen and Mccready (1975) and Mostafa et al., (1987). Carbohydrates and energy was increased significantly during roasting and popping while decreased during germination. The increased value of carbohydrates in popped chia is related to the decrease in dry matter as a consequence of oil extraction. The results are in line with the findings of Benincasa $e t$ al., (2019). The higher energy content of roasted chia seeds might be due to high calorific value. Coelho (2014) reported a caloric value of $431 \mathrm{Kcal} / 100 \mathrm{~g}$ in chia seeds and associates the caloric value with its high levels of lipids.

Table.1 Effect of treatment on proximate analysis of flax, chia, pumpkin and finger millet seeds

\begin{tabular}{|c|c|c|c|c|c|c|}
\hline Parameter & Seeds & T0 & T1 & $\mathbf{T 2}$ & T3 & $C D(p \leq 0.5)$ \\
\hline \multirow[t]{4}{*}{ Moisture (\%) } & $\mathrm{F}$ & 10.06 & 9.41 & 8.40 & 10.17 & NS \\
\hline & $\mathrm{C}$ & 5.53 & 4.60 & 4.07 & 4.73 & 0.97 \\
\hline & $\mathrm{P}$ & 5.79 & 5.63 & 5.74 & 6.10 & NS \\
\hline & FM & 9.94 & 9.40 & 7.87 & 10.02 & 1.38 \\
\hline \multirow[t]{4}{*}{ Total ash (\%) } & $\mathrm{F}$ & 4.55 & 4.54 & 4.20 & 3.26 & NS \\
\hline & $\mathrm{C}$ & 4.01 & 3.30 & 3.50 & 4.88 & 0.90 \\
\hline & $P$ & 6.78 & 6.57 & 6.63 & 6.63 & NS \\
\hline & FM & 2.63 & 2.56 & 2.59 & 2.12 & NS \\
\hline \multirow[t]{4}{*}{ Crude protein (\%) } & $\mathrm{F}$ & 22.18 & 20.73 & 19.14 & 22.81 & 1.67 \\
\hline & $\mathrm{C}$ & 25.25 & 22.32 & 21.83 & 27.33 & 1.48 \\
\hline & $\mathrm{P}$ & 22.96 & 21.66 & 20.91 & 29.03 & 0.51 \\
\hline & FM & 8.72 & 8.03 & 8.34 & 9.04 & NS \\
\hline \multirow[t]{4}{*}{ Crude fat (\%) } & $\mathrm{F}$ & 43.59 & 42.77 & 42.23 & 41.65 & NS \\
\hline & $\mathrm{C}$ & 29.54 & 28.95 & 27.90 & 27.39 & 0.96 \\
\hline & $P$ & 32.62 & 29.69 & 28.34 & 30.23 & NS \\
\hline & FM & 1.51 & 2.01 & 1.95 & 1.44 & NS \\
\hline \multirow[t]{4}{*}{ Crude fiber (\%) } & $\mathrm{F}$ & 11.97 & 10.61 & 10.11 & 8.37 & 1.64 \\
\hline & $\mathrm{C}$ & 21.63 & 23.21 & 22.56 & 22.02 & 0.63 \\
\hline & $\mathrm{P}$ & 6.55 & 6.17 & 5.37 & 7.65 & 1.03 \\
\hline & FM & 4.67 & 4.58 & 4.44 & 4.65 & NS \\
\hline \multirow[t]{4}{*}{ Carbohydrate (\%) } & $\mathrm{F}$ & 17.72 & 21.35 & 24.32 & 23.91 & 4.06 \\
\hline & $\mathrm{C}$ & 19.37 & 22.58 & 24.33 & 19.05 & 3.32 \\
\hline & $\mathrm{P}$ & 31.59 & 29.21 & 27.80 & 27.11 & 1.52 \\
\hline & FM & 82.47 & 82.82 & 82.68 & 82.76 & NS \\
\hline \multirow[t]{4}{*}{ Energy (Kcal/100g) } & $\mathrm{F}$ & 551.93 & 553.22 & 553.91 & 561.75 & NS \\
\hline & $\mathrm{C}$ & 446.17 & 459.29 & 448.22 & 432.00 & 13.66 \\
\hline & $\mathrm{P}$ & 490.34 & 489.80 & 486.21 & 514.57 & NS \\
\hline & FM & 378.38 & 381.52 & 381.61 & 380.1 & NS \\
\hline
\end{tabular}

Value significant at 5\% level of significance

$\mathrm{F}=$ Flaxseed, $\mathrm{C}=$ Chia seed, $\mathrm{P}=$ Pumpkin seed and $\mathrm{FM}=$ Finger Millet 
Table.2 Effect of treatment on mineral analysis of flax, chia, pumpkin and finger millet seeds

\begin{tabular}{|c|c|c|c|c|c|c|}
\hline Parameters & seeds & T0 & T1 & $\mathbf{T 2}$ & T3 & $\mathrm{CD}(\mathrm{p} \leq 0.05)$ \\
\hline \multirow{4}{*}{$\begin{array}{l}\text { Calcium } \\
(\mathrm{mg} / \mathbf{1 0 0 g})\end{array}$} & $\mathrm{F}$ & 168.29 & 143.95 & 138.39 & 152.43 & 2.05 \\
\hline & $\mathrm{C}$ & 620.75 & 617.24 & 611.13 & 646.28 & 26.55 \\
\hline & $\mathrm{P}$ & 10.27 & 9.05 & 8.78 & 10.61 & 1.21 \\
\hline & FM & 341.25 & 330.92 & 300.13 & 349.60 & NS \\
\hline \multirow{4}{*}{$\begin{array}{c}\text { Phosphorus } \\
\text { (mg/100g) }\end{array}$} & $\mathrm{F}$ & 361.78 & 281.61 & 260.92 & 400.49 & 12.30 \\
\hline & $\mathrm{C}$ & 854.25 & 760.40 & 667.82 & 884.72 & 145.1 \\
\hline & $\mathrm{P}$ & 46.62 & 45.16 & 44.66 & 48.10 & 1.86 \\
\hline & FM & 278.33 & 269.32 & 260.29 & 271.88 & 2.98 \\
\hline \multirow{4}{*}{$\begin{array}{c}\text { Iron } \\
(\mathrm{mg} / 100 \mathrm{~g})\end{array}$} & $\mathrm{F}$ & 5.61 & 5.01 & 4.54 & 8.22 & 1.11 \\
\hline & $\mathrm{C}$ & 4.36 & 5.71 & 4.32 & 7.76 & 1.50 \\
\hline & $\mathrm{P}$ & 3.88 & 2.66 & 2.17 & 4.14 & 0.80 \\
\hline & FM & 3.30 & 2.76 & 3.15 & 3.70 & NS \\
\hline
\end{tabular}

Value significant at 5\% level of significance

$\mathrm{F}=$ Flaxseed, $\mathrm{C}=\mathrm{Chia}$ seed, $\mathrm{P}=$ Pumpkin seed and $\mathrm{FM}=$ Finger Millet

\section{Pumpkin seeds}

Proximate analysis parameters of the different processing treatment pumpkin seeds only showed significant difference in crude protein, crude fiber and carbohydrates. Significant increase in crude protein of germinated pumpkin seed enhanced protein synthesis due to inclusion of microbial cells in to the flour (Anonymous, 2008). The reduction in protein content after roasting and popping may be due to denaturation and coagulation of protein. The present study findings are in line with Bradbury and Halloway (1988) reported that heating process denatures the protein. The increase during germination might be due to increase in dietary fiber content than other processing and increase mineral bioavailability. Ghavidel and Prakash (2007) also concluded the same as reported in the present study. Roasting and popping decreased the crude fiber while it remains same as that of raw seeds during germination. Carbohydrate decreased in all the processing treatments with maximum decrease shown in germination. The reduction of carbohydrate content during germination may be due to decreased starch digestibility during sprouting that resulted in slow hydrolytic activities of the enzymes during sprouting. The results are in agreement with the findings of Mubarak (2005), for germinated samples which showed a significant reduction in the carbohydrate content. Akinijayeju et al., (2007) in their study reported that the carbohydrate by alpha amylases to simple and more soluble sugars needed by the growing seeds.

\section{Finger Millet}

All the proximate analysis parameters showed non-significant difference during processing of the finger millet except the moisture content. Popping leads to $20.82 \%$ decrease in moisture content when compared to the raw seeds. In finger millet moisture was significantly decreased during popping and roasting but vice-versa was observed during germination. Malik et al., (2002) also reported decrease in moisture content in pearl millet during thermal processing by vaporization of water. 


\section{Mineral analysis}

The mineral analysis of flax, chia, pumpkin and finger millet seeds are shown in Table 2. Significant differences $(p \leq 0.05)$ were observed during processing of oilseeds in Calcium, Phosphorus and Iron content of flaxseed, chia seeds and pumpkin seeds. However, Finger millet showed significant differences in Phosphorus content.

\section{Flaxseed}

Calcium content of the flaxseed decreased during all the processing methods with maximum decrease $(17.77 \%)$ shown in popping. The decrease in calcium content during roasting and popping might be due to the losses of minerals during heat treatments. Similar results were reported by Hassan (2013) that there was significant $(\mathrm{P} \leq 0.05)$ decrease in calcium content of raw sesame seed when compared with roasted sesame seed. Results of present investigation are in close agreement with findings of (Singh et al., 1990) that in germinated flaxseed varieties, a significant reduction was observed for calcium. Phosphorus was increased $(10.70 \%)$ during germination but decreased during roasting and popping. Singh et al., (1990) reported that there was a slight increase in phosphorous content was noted in germinated flaxseed varieties. About 70\% of phosphorous in flaxseeds occur as phytate inositol hexaphosphate, which during germination get converted into soluble free phosphorous by the action of phytase, which might be the probable reason for increase in phosphorous content. Iron content was significantly increased (46.52) only during germination. Increase in iron content during germination was also reported by Narina et al., (2012) in the flaxseed sprouts. Berghofer and Schoenlechner (2002) also reported decrease in iron content that could be attributed to the loss of pericarp during popping as more than
$66 \%$ of total minerals were found in the bran and germ fractions in amaranth).

\section{Chia seeds}

Roasting and popping leads to decrease in the calcium content of the chia seeds. CalvoLerma et al., (2020) also reported that germination promotes the hydrolysis of chia proteins, making them completely digestible, and causes a significant increase in polyphenols and calcium concentration in chia sprouts. Phosphorus content was significantly increased (3.57\%) during germination, while it decreased significantly during roasting and popping. Germination induces changes in the concentration of minerals, as was observed in phosphorus concentration of chia sprouts, probably as a consequence of an increase in its extractability. This was also supported by Guzmán-Ortiz et al., (2017) in their study while evaluating the effect of germination on the seeds. Iron content was increased during roasting and germination of the raw seeds up to 30.96 and $77.98 \%$ respectively.

\section{Pumpkin seeds}

Mineral content of germinated pumpkin seeds significantly increased, while during roasting and popping it decreased significantly As evident from Table 2 Calcium, phosphorus and Iron increased from 10.27, 46.62 and 3.88 $(\mathrm{mg} / 100 \mathrm{~g})$ to $10.61, \quad 48.10$ and 4.14 $(\mathrm{mg} / 100 \mathrm{~g})$ during germination. El-Adawy and Taha (2001) in their study reported moderate concentrations of minerals in pumpkin seed kernels. Increase in iron content during germination could be as a result of activities of microorganism and bio-synthesis during processing (Steve et al., 2011). The reduction of iron during roasting and popping could be due to the very short processing time during cooking (high temperature, short time) unlike roasting. This significant decrease in iron 
content during roasting and popping could be explained by the high temperature.

\section{Finger millet}

Processing of finger millet seeds resulted in significant decrease in phosphorus content while iron and calcium varied nonsignificantly. Mineral analysis of finger millet revealed that calcium content was nonsignificantly increased and decreased significantly during germination and popping respectively. This might be due to decreases of oxalic acid during sprouting, correspondingly increases calcium content in finger millet because oxalic acid is known to interfere with calcium absorption.

The results of present study for the decrease in iron content could be explained by the high temperature during roasting and popping. Popping resulted in decreasing the phosphorus content from 278.33 to 260.29 $\mathrm{mg} / 100 \mathrm{~g}$. Chauhan and Sarita (2018) also reported significant decrease in phosphorus content during germination. Decrease in Iron content was in agreement with the findings of Tizazu (2011). The decrease of phosphorus content during roasting and popping might be due to the high temperature. Increase in iron content during germination was also reported by Gunashree et al., (2014).

In conclusion the processing of seeds substantially enhanced the nutritional profile and bioavailability of the minerals. Germinated seeds have higher protein, carbohydrates and minerals content as compared to raw seeds. Energy of chia seeds significantly increased during popping and roasting but decreased during germination. Among all the processed seeds, Chia seed was having highest increase calcium and iron, while Flaxseed was having highest phosphorus content after germination.

\section{Acknowledgement}

We convey our heartfelt thanks to our Head of Department for best cooperation and the faculty of Department of Animal Nutrition, DGCN COVAS, CSKHPKV for providing laboratory facilities for conducting the present study.

\section{References}

Anonymous.2008.http://en.wikipedia.org/wiki /sprouting.Nutritional information. Accessed on 02/09/2020.

Agbagwa, I. O., and Ndukwu, B. C. 2004. The value of morpho-anatomical features in the systematics of Cucurbita L. (Cucurbitaceae) species in Nigeria. African Journal of Biotechnology 3(10), 541-546.

Alfawaz, M. A. 2004. Chemical composition and oil characteristics of pumpkin (Cucurbita maxima) seed kernels. Food Science and Agriculture 2(1): 5-18.

Ananthan, P., Sharma, G. K., Thimma, G., and Bawa, A. S. 2012. Development of a Shelf- Stable Omega-3- Rich Bar. Journal of Food Quality 35(6): 383389.

AOAC. 2010. Official methods of analysis, 18th edition, Association of Official Analytical Chemists, Washington DC

Bau, H. M., Villaume, C., Nicolas, J. P., and Méjean, L. 1997. Effect of germination on chemical composition, biochemical constituents and antinutritional factors of soya bean (Glycine max) seeds. Journal of the Science of Food and Agriculture 73(1):1-9.

Benincasa, P., Falcinelli, B., Lutts, S., Stagnari, F., and Galieni, A. 2019. Sprouted grains: A comprehensive review. Nutrients 11(2): 421.

Cahill, J. P., and Provance, M. C. 2002. Genetics of qualitative traits in domesticated chia (Salvia hispanica 
L.). Journal of Heredity 93(1): 52-55.

Caili, F. U., Huan, S., and Quanhong, L. I. 2006. A review on pharmacological activities and utilization technologies of pumpkin. Plant foods for human nutrition 61(2): 70-77.

Chen, P. S., Toribara, T. T., and Warner, H. 1956. Microdetermination of phosphorus. Analytical chemistry 28(11): 1756-1758.

Coelho, M. S., and Salas-Mellado, M. D. L. M. 2014. Chemical characterization of chia (Salvia hispanica L.) for use in food products. Journal of Food and Nutrition Research 2(5): 263-269.

Elmaki, H. B., Babiker, E. E., and El Tinay, A. H. 1999. Changes in chemical composition, grain malting, starch and tannin contents and protein digestibility during germination of sorghum cultivars. Food chemistry 64(3): 331336.

Gopalan, C., Rama Sastri, B. V., and Balasubramanian, S. C. 1971. Nutritive value of Indian foods.

Inyang, C. U., and Zakari, U. M. 2008. Effect of germination and fermentation of pearl millet on proximate, chemical and sensory properties of instant "Fura"-a Nigerian cereal food. Pakistan Journal of Nutrition, 7(1): 9-12.

Izzo, M., and Niness, K. 2001. Formulating nutrition bars with inulin and oligofructose. Cereal Foods World 46(3), 102-106.

Jamboonsri, W., Phillips, T. D., Geneve, R. L., Cahill, J. P., and Hildebrand, D. F. 2012. Extending the range of an ancient crop, Salvia hispanica L. - a new $\omega 3$ source. Genetic Resources and Crop Evolution 59(2) : 171-178.

Kajla, P., Sharma, A., and Sood, D. R. 2015. Flaxseed - a potential functional food source. Journal of food science and technology 52(4) : 1857-1871.

Bradbury, J. H., and Holloway, W. D. (1988).
Tropical Root Crops of the South Pacific: Chemistry, Nutrition and Agriculture.

Kylen, A. M and Mccready, R. M. 1975. Nutrients in seeds and sprouts of alfalfa, lentils, mung beans and soybeans.

Marques, T. R., Corrêa, A. D., de Carvalho Alves, A. P., Simão, A. A., Pinheiro, A. C. M., and de Oliveira Ramos, V. 2015. Cereal bars enriched with antioxidant substances and rich in fiber, prepared with flours of acerola residues. Journal of food science and technology 52(8): 5084-5092.

Mayer, A. M., and Poljakoff-Mayber, A. 1982. The Germination of Seeds: Pergamon International Library of Science, Technology, Engineering and Social Studies. Elsevier.

Morris, D. H. (2004). Other health benefits of flax. Flax: A Health and Nutrition Primer Flax Council of Canada, Winnipeg, Manitoba, Canada, 59-63.

Mostafa, M. M., Rahma, E. H., and Rady, A. H. 1987. Chemical and nutritional changes in soybean during germination. Food Chemistry 23(4): 257-275.

Mueller, K., Eisner, P., Yoshie-Stark, Y., Nakada, R., and Kirchhoff, E. 2010. Functional properties and chemical composition of fractionated brown and yellow linseed meal (Linum usitatissimum L.). Journal of Food Engineering 98(4): 453-460.

Oomah, B. D., and Mazza, G. 1998. Compositional changes during commercial processing of flaxseed. Industrial Crops and Products 9(1): 2937.

Özdemir, M., and Devres, O. 2000 ${ }^{\mathrm{a}}$. Analysis of color development during roasting of hazelnuts using response surface methodology. Journal of Food Engineering 45(1): 17-24.

Özdemir, M., and Devres, O. $2000^{\mathrm{b}}$. Kinetics 
of color changes of hazelnuts during roasting. Journal of Food Engineering 44(1) : 31-38.

Palazzolo, G. 2003. Cereal bars: they're not just for breakfast anymore. Cereal Foods World, 48(2) : 70.

Pittia, P., Dalla Rosa, M., and Lerici, C. R. 2001. Textural changes of coffee beans as affected by roasting conditions. LWT-Food Science and Technology 34(3): 168-175.

Sharma, C., Kaur, A., Aggarwal, P., and Singh, B. 2014. Cereal Bars--A Healthful Choice A Review. Carpathian Journal of Food Science and Technology 6(2).

Singh, K. K., Mridula, D., Barnwal, P., and Rehal, J. 2013. Selected engineering and biochemical properties of 11 flaxseed varieties. Food and Bioprocess Technology 6(2): 598-605.

Marques, T. R., Corrêa, A. D., de Carvalho Alves, A. P., Simão, A. A., Pinheiro, A. C. M., and de Oliveira Ramos, V. 2015. Cereal bars enriched with antioxidant substances and rich in fiber, prepared with flours of acerola residues. Journal of food science and technology 52(8): 5084-5092.

Wang, H. X., and Ng, T. B. 2003. Isolation of cucurmoschin, a novel antifungal peptide abundant in arginine, glutamate and glycine residues from black pumpkin seeds. Peptides 24(7): 969972.

Weber, C. W., Gentry, H. S., Kohlhepp, E. A., and McCrohan, P. R. 1991. The nutritional and chemical evaluation of chia seeds. Ecology of Food and Nutrition 26(2): 119-125.

Ghavidel, R. A., and Prakash, J. 2007. The impact of germination and dehulling on nutrients, antinutrients, in vitro iron and calcium bioavailability and in vitro starch and protein digestibility of some legume seeds. LWT-Food Science and
Technology 40(7): 1292-1299.

Mubarak, A. E. 2005. Nutritional composition and antinutritional factors of mung bean seeds (Phaseolus aureus) as affected by some home traditional processes. Food chemistry 89(4): 489-495.

Akinijayeju, O. and Francis. 2007. Effects of sprouting on the proximate composition of bambara nut flours. Processing of the annual conference/general meeting of NFST, Oct-22- 25:158-159.

Malik, M., Singh, U., and Dahiya, S. 2002. Nutrient composition of pearl millet as influenced by genotypes and cooking methods. Journal of food science and technology (Mysore) 39(5): 463-468.

Singh, R. P., and Vinay, S. 1990. Effect of S, $\mathrm{Mg}$ and $\mathrm{K}$ on yield and uptake by linseed. Journal of the Indian Society of Soil Science 38(1), 169-170.

Narina, S. S., Hamama, A. A., and Bhardwaj, H. L. 2012. Nutritional and mineral composition of flax sprouts. Journal of Agricultural Science 4(11): 60.

Berghofer, E., and Schoenlechner, R. 2002. Grain amaranth. In Pseudocereals and less common cereals (pp. 219-260). Springer, Berlin, Heidelberg.

Calvo-Lerma, J., Paz-Yépez, C., AsensioGrau, A., Heredia, A., and Andrés, A. 2020. Impact of Processing and Intestinal Conditions on in Vitro Digestion of Chia (Salvia hispanica) Seeds and Derivatives. Foods 9(3): 290. Guzmán-Ortiz, F. A., San Martín-Martínez, E., Valverde, M. E., Rodríguez-Aza, Y., Berríos, J. D. J., and MoraEscobedo, R. 2017. Profile analysis and correlation across phenolic compounds, isoflavones and antioxidant capacity during germination of soybeans (Glycine max L.). CyTA-Journal of Food 15(4): 516-524.

El-Adawy, T. A., and Taha, K. M. 2001. Characteristics and composition of different seed oils and flours. Food 
chemistry 74(1):47-54.

Steve, I. O. 2011. Influence of germination and fermentation on chemical composition, protein quality and physical properties of wheat flour (Triticum aestivum). Journal of Cereals and Oilseeds 3(3): 35-47.

Chauhan, E. S. and Sarita. 2018. Effects of processing (germination and popping) on the nutritional and anti-nutritional properties of finger millet (Eleusine coracana). Current Research in Nutrition and Food Science Journal 6(2): 566-572.

Tizazu, S., Urga, K., Belay, A., Abuye, C., and Retta, N. 2011. Effect of germination on mineral bioavailability of sorghum-based complementary foods. African Journal of Food, Agriculture, Nutrition and Development 11(5): 5083-5095.

Gunashree, B. S., Selva Kumar, R., Roobini, R., and Venkateswaran, G. 2014. Nutrients and antinutrients of ragi and wheat as influenced by traditional processes. International Journal of Current Microbiology and Applied Sciences 3(7): 720-736.

\section{How to cite this article:}

Diksha Sharma and Sangita Sood. 2020. Effect of Processing on Selected Nutrient Profile of Seeds used for Inclusion in Energy Bars of Sports Person. Int.J.Curr.Microbiol.App.Sci. 9(09): 3095-3105. doi: https://doi.org/10.20546/ijcmas.2020.909.382 